九州大学学術情報リポジトリ

Kyushu University Institutional Repository

\title{
A New Subgenus of the Genus Andrena (Hymenoptera, Andrenidae) from Japan and Allied Areas
}

Hirashima, Yoshihiro

Entomological Laboratory, Department of Agriculture, Kyushu University

Tadauchi, Osamu

Entomological Laboratory, Department of Agriculture, Kyushu University

https://doi.org/10.5109/22880

出版情報：九州大学大学院農学研究院紀要. 19 (4)，pp.175-186，1975-06. Kyushu University バージョン：

権利関係 : 
J. Fac. Agr., Kyushu Univ., 19, 175-186 (1975)

\title{
A New Subgenus of the Genus Andrena (Hymenoptera, Andrenidae) from Japan and Allied Areas*
}

\author{
Yoshihiro Hirashima and Osamu Tadauchi \\ Entomological Laboratory, Faculty of Agriculture, \\ Kyushu University, Fukuoka
}

(Received March 22, 1975)

\begin{abstract}
O reomelissa, a new subgenus of the genus Andrena is erected for the mitakensis group of the subgenus Calomelissa Hirashima et LaBerge, 1963. One of the European species, Andrena coitana (Kirby), which is here included in Oreomelissa, is recorded from Japan for the first time (subsp. pilosodorsata Alfken). Also, Andrena mitakensis Hirashima is newly recorded from Korea. A key is presented for the species (3 spp.) of Oreomelissa, and a detailed redescription of Andrena coitana pilosodorsata is given.
\end{abstract}

In the systematic study of the family Andrenidae of Japan (Hirashima, 1963 p. 246), Hirashima and LaBerge erected a new subgenus Calomelissa for four Asiatic species. It was originally devided into two groups, the prostomias group and the mitakensis group. Since the mitakensis group deviates from theprostomias group in having the propodeal enclosure smaller with the sides not convex outwardly, the tibia1 scopa composed of more loose hairs, the dorsal face of the propodeum as well as the mesopleuron more densely tessellate or shagreened, the facial foveae much narrower and the first intercubital vein close to the pterostigma, Hirashima and LaBerge hesitantly included the mitakensis group in the subgenus Calomelissa and suggested that it may represent a separate subgenus (Hirashima, Zoc. cit.). Recently, Tadauchi (in press) also found that the two species groups are recognized better to be raised to the subgeneric level from the result of a numerical taxonomic study of the genus Andrena of Japan.

Our critical studies on the mitakensis group based on materials newly gathered from various sources revealed clearly the interspecific relationship as well as the subgeneric position of the group. This paper reports results of our recent studies on the group containing a proposal of a new subgenus for it.

Misidentifications which were made recently by some European authors in relation to the recognition of the subgeneric status of Andrena coitana (Kirby) is here pointed out. When they erected the subgenus Calomelissa, Hirashima and LaBerge suggested that Andrena coitana may be a member of the mitakensis group of Calomelissa (Hirashima, loc. cit.). In 1968, however, Warncke treated Andrena coitana as a member of Stenomelissa Hirashima et LaBerge, 1965, not seeing the original descriptions of both Calomelissa and Stenomelissa but according to a personal

\footnotetext{
* Contribution from the Entomological Laboratory, Faculty of Agriculture, Kyushu University,
} Fukuoka (Ser. 3, No. 23). 
opinion of Grünwaldt (Warncke, 1968, p. 42). This is a remarkable error. Consequently, LecLercq (1972), for example, erroneously placed Andrena coitana to Stenomelissa again. So far as we know, Stenomelissa is an unique monobasic subgenus of Andrena based on the Japanese species Andrena halictoides Smith.

Oreomelissa Hirashima et Tadauchi, subg. $n$. ö os mountain, and $\mu \dot{\varepsilon} \lambda \epsilon \sigma \sigma \alpha$ bee.

Type-species :Andrena mitakensis Hirashima, 1963.

The new subgenus is proposed for the mitakensis group of the subgenus Calomelissa Hirashima et LaBerge, 1963.

Diagnosis: This new subgenus is readily distinguished from others by the combination of characters such as the first intercubital vein close to the pterostigma, the dorsal face of the propodeum not roughened and the tibia1 scopa composed of very loose hairs. Excepting the unique venation of the new subgenus, it seems that it is related to Notandrena and Calomelissa. The new subgenus can be, however, distinguished from Notandrena in having the poorly developed propodeal corbicula, the triangular process of labrum in the female and the presence of brownish hairs on the head and thorax and from Calomelissa in having the more densely tessellate or shagreened mesopleuron, the facial fovea much narrower and the propodeal enclosure smaller with the sides not convex outwardly. The subgenus Micrandrena also has the first intercubital vein close to the pterostigma, but it can be separated from the new subgenus by the coarsely sculptured dorsal face of propodeum, the entire process of labrum, and the compact tibia1 scopa. It is further characterized in having the long maxillary palpi, the relatively short galeae and the normal posterior spur of the hind tibiae.

So far as the present paper is concerned, the new subgenus is represented by three species known from Japan and allied areas. One of them, however, is Andrena coitana (Kirby) which widely occurs in the Palaearctic Region from England to Japan (new record) and Kamchatka. So far as our investigation goes, Japanese species of Oreomelissa inhabits the mountainous regions of Honshu (central and northern districts) and Hokkaido. Hence the name of the subgenus They fly in summer and autumn there.

Description :Female and male : Small to medium sized species, integument black. Head of moderate size, about as broad as thorax seen from above, more or less rounded in front view ; facial quadrangle longer than broad; malar space almost obsolescent ; eyes with inner margins subparallel ; clypeus more or less well convex; process of labrum nearly triangular ; maxillary palpi longer than galea by last two palpal segments when both are extended; subgenal coronet present; genal area about as broad as eyes seen in profile. Thorax with mixed hairs; pronotal ridge weakly present; mesopleuron densely tessellate ; enclosure of propodeum large, approximately triangular ; dorsal face of propodeum densely tessellate, not roughened. Wings with three submarginal cells: 1st intercubital vein close to pterostigma; 1st recurrent vein beyond middle or near end of second submarginal cell. Legs with normal posterior spur of hind tibiae. Metasoma smooth or weakly tessellate; posterior depressions of metasomal terga more or 


\section{less broad.}

Female : Facial fovea separated from eye margin by a narrow raised space, with upper end occupying about one-half of distance between orbits and post ocelli; antennae with 3rd segment as long as or longer than next two segments together. Propodeal corbicula not well developed, with dorsal fringe of short, scanty hairs ; interior of corbicula with short, sparse, simple hairs. Trochanteral floccus imperfect or nearly perfect, with scanty hairs; femoral floccus sparse with hairs simple ; tibia1 scopa composed of loose, simple hairs ; mid basitarsi not expanded medially, narrower than hind basitarsi. First metasomal terga almost bare; posterior margins of 2 nd to 4 th metasomal terga with appressed hair fringes; sterna with poorly formed subapical fimbriae ; pygidial plate with raised median triangular area; graduli present on 1st and 2nd metasomal sterna.

Male: Clypeus entirely and lower paraocular areas narrowly to more or less broadly ivory white, with or without a pair of black spots on clypeus sublaterally; cheeks well developed, as broad as or broader than large eyes as seen in profile. Second to 5th metasomal sterna with poorly formed subapical fimbriae ; 6th metasomal sternum reflexed apically with a triangular concavity in middle of apical portion; graduli present on 1st to 6th metasomal sterna.

Distribution : Palaearctic Region.

Included species : Three species, Andrena mitakensis Hirashima, Andrenakamikochiana Hirashima and Andrena coitana (Kirby).

Note : Although we examined a pair of European specimens of Andrena coitana (Kirby) (det. by Dr. Erlandson of Sweden), we are not very familiar with that species. Therefore, we designated Andrena mitakensis Hirashima as the type species of 0 reomelissa for certainty.

\section{Key to the species of Oreomelissa occurring in Japan and allied areas}

Female

1. Larger, length about $11 \mathrm{~mm}$; lower paraocular areas smooth and shiny ; propodeal enclosure more or less well defined ; dorsal face of propodeum and mesopleuron with weak punctures; metasoma smooth and shiny...

\section{mitakensis}

- Smaller, length about or less than $8.5 \mathrm{~mm}$; lower paraocular areas densely tessellate ; propodeal enclosure ill defined ; dorsal face of propodeum and mesopleuron nearly impunctate ; metasoma very finely tessellate ........2

2. Clypeus nearly shagreened all over (Fig. 4) ; process of labrum smaller, triangular, roundly well convex apically (Fig. 4) ; mesoscutum, scutellum and dorsal face of propodeum densely tessellate ............kamikochiana

- Clypeus tessellate basally, nearly smooth apically (Fig. 6) ; process of labrum larger, slightly but broadly convex (Fig. 6) ; mesoscutum, scutellum and dorsal face of propodeum weakly tessellate 
Male

1. Larger, length about $10 \mathrm{~mm}$; clypeus well convex medially ; mandibles long, with lower teeth much exceeding inner ones and curved inward ; antennae with 3rd segment more than twice as long as broad, 4th segment slightly longer than broad; dorsal face of propodeum tessellate with an indication of weak punctures: genitalia with parapenial lobe shorter ................................................................ mitakensis

- Smaller, length about or slightly over $7 \mathrm{~mm}$ : clypeus slightly convex medially; mandibles shorter, with lower teeth not much exceeding inner ones, not specially curved: antennae with 3rd segment twice as long as broad, 4th segment indistinctly broader than long; dorsal face of propodeum densely tessellate, nearly impunctate ; genitalia with parapenial lobe elongate ....................................................... 2

2. Clypeus (with ivory white marking) prolonged laterally (Fig. 5) ; lower paraocular areas densely tessellate, with larger ivory white maculae (Fig. 5); head and mesoscutum with much darker hairs.

kamikochiana

- Clypeus (with ivory white marking) nearly semicircular (Fig.7) ; lower paraocular areas less tessellate, with smaller ivory white maculae (Fig. 7 ); head and mesoscutum with less darker hairs . . . . . . . coitana pilosodorsata

\section{Andrena (Oreomelissa) mitakensis Hirashima}

Andrena (Calomelissa) mitakensis Hirashima, 1963, J. Fac. Agr., Kyushu Univ., 12: 248, female and male. (Description)

Andrena (Calomelissa) mitakensis: Hirashima, 1966, J. Fac. Agr., Kyushu Univ., 14 : 112 (female), 113 (male). (Key)

The female of this species can be distinguished from that of other species of 0 reomelissa by the larger size, the elongate, smooth and shiny metasomal terga, the punctate dorsal face of propodeum and the more or less well defined propodeal enclosure. The male is more easily recognizable by the well convex clypeus, the longer and curved mandibles and the shorter parapenial lobe of gonocoxite.

According to the collecting data, this species occurs in northern Japan (Tohoku District and Hokkaido), central Honshu (mountainous regions only) and northern Korea (Mt. Kongo) (new record). One female specimen from the latter locality before us shows the clypeus nearly smooth and the punctures on the body (clypeus, vertex, mesoscutum, scutellum and metasomal terga) stronger and larger in comparison with the specimens from Japan. The population of this species in this part of Korea may represent a separate subspecies, but it is provisionally included in the nominate form in this paper.

The Aying season of this species is relatively later and the habitats are lower in altitude (about or slightly lower than $1,500 \mathrm{~m}$ ) than in kamikochiana in central Honshu. It is interesting, however, that the two species, mitakensis and kamikochiana, are collected at the same time in the same place such as Ono City, Fukui Pref. and Nikkoh-Yumoto, Tochigi Pref. From the phenological 


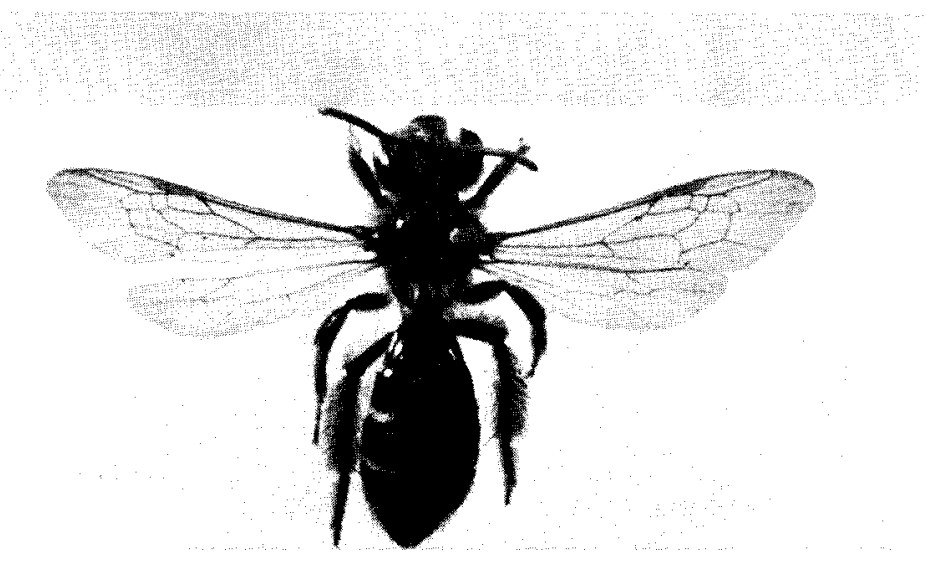

Fig. 1. Female of Andrena(Oreomelissa) mitaken sis Hirashima.

studies of bees at Hakodateyama in Hokkaido, Matsumura and Munakata (1969) reported that this species appears from middle August to early October.

Distribution: Japan (Hokkaido and central and northern Honshu) and Korea (Mt. Kongo). This is the first record of this species from Korea.

Flower records: Females and malts have been collected on Lactuca denticulata Maxim., Picris hieracioides var. japonica Rcgel, Cirsium sp., Cosmos bipinnatus Cav., Salvia nipponica Miq. and Aralia cordata Thunb. According to Matsumura and Munakata (1969), this species is highly eurytrophic, and frequents on Compositae, and next on Geranium nepalensis and Achyranthes japonicus.

Specimens examined : Japan, Honshu :4 $2 \precsim$, Yokoyama, Ina, Nagano Pref., 14. ix. 1961 (Y.Maeta); $12 \precsim$. Yokoyama, Ina, Nagano Pref., 17. ix. 1962 (Y. Maeta); 1 ๖, Ono City, Fukui Pref., 20. viii. 1964 (Y. Haneda) ; 1 ?, Ono City, Fukui Pref., 9. ix. 1973 (Y. Haneda) ; 1 ९ $\precsim$, Ono City, Fukui Pref., 16. ix. 1973 (Y. Haneda) ; 1 , Kuriyagawa, Morioka, Iwatc Pref., 4. x. 1971 (Y. Maeta). Hokkaido: 1 , Nishiashoro, Tokachi, 6. viii. 1953 (Y. Hirashima) ; 1 , Aizankei, Mt. Daisetsu,30. vii-3. viii. 1955 (Y. Hirashima) ;2 Nakagawa, Nakagawa Exp. Forests, 6. ix. 1970 (S. F. Sakagami and II. Fukuda). Korea: 1 ', Mt. Kongo, Kogrndo. 10. ix. 1931 (C. Takeya).

\section{Andrena (Oreomelissa) kamikochiana Hirashima}

Andrena (Calomelissa) kamikochiana Hirashima. 1963, J. Fnc. Agr., Kyushu Univ., 12: :251, female and male. (Description)

Andrena (Cafomelissa) kamikochiana : Hirashima, 1966, J. Fac. Agr., Kyushu Univ., 14:11: (female), 113 (male). (Key)

This species is very similar to the following species Andrena coitana (Kirby) which is distributed in the Eurasian Continent, although primarily northern. It is separated from coitana by the female clypeus being more shagrcencd and dull, 
the mesoscutum as well as scutellum more densely tessellate and the process of labrum smaller with apex well convex roundly. The male of kamikochiana is separable from that of coitana in having the clypeus (with ivory white maculae) more prolonged laterally, the lower paraocular areas (with larger ivory white maculae) more densely tessellate and the hairs on the head and mesoscutum much darker.

Although Hirashima (1963) recorded this species from Hokkaido and central Honshu, our recent studies revealed that the population in Hokkaido should be recognized as Andrena coitana pilosodorsata Alfken as stated below. Thus, Andrena kamikochiana is known only from Honshu at present. In Honshu, the habitats of kamikochiana are restricted to more mountainous regions (about or more than $1,500 \mathrm{~m}$ ).

Distribution : Japan (central and northern Honshu).

Flower record : One female and 8 males were collected on Solidagovirga-aurea L. on Mt. Yatsugatake, Nagano Pref.

Specimens examined : 1 우, Daimonsawa, Mt. Notoridakc, Yamanashi Pref., 8. viii. 1972 (0. Tadauchi) ;1ð, Sunaharai, Mt. Hôou, Yamanashi Prcf., 8 viii. 1973 (0. Tadauchi) ; 1 우 $8 \precsim ð$, Mt. Yatsugatake, Nagano Pref., 7. viii. 1974 (0. Ta-

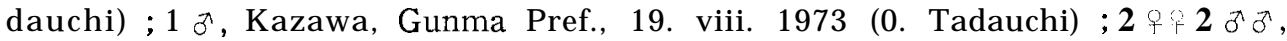
Mt. Haku, Ishikawa Pref., 23. viii. 1972 (I. Togashi); $3 \precsim \precsim$, Mt. Haku, Ishikawa Pref., 28. vii. 1972 (I. Togashi); $4 \precsim \partial$, Mt. Haku, Ishikawa Pref., vii. 1973 (I. Togashi); 1 f, Ono City, Fukui Pref., 16. ix. 1973 (Y. Haneda) ; 4 우 1 , Mt. Hayachine, Iwate Pref., 29. viii. 1972 (M. Honda).

\section{Andrena (Oreomelissa) coitana pilosodorsata Alfken}

Andrena coitana var. pilosodorsata Alfken, 1929, Ark. 2001. 20A, 16: 6, female and male. (D escription)

Andrena coitana pilosodorsata: Yasumatsu, 1941, Peking nat. Hist. Bull., 15 : 275. (List only) Andrena (Calomelissa) kamikochiana Hirashima, 1963, J. Fac. Agr., Kyushu Univ., 12 : 253, female and male, in part. (Description)

This was recorded from Kamchatka as a variety of Andrena coitana (Kirby) of Europe but we recognize this as a subspecies. It is distinguished from the nominate subspecies by the clypeus, mesoscutum and metasomal terga with punctures weaker and sparser, the mesoscutum and scutellum with hairs longer and denser, the posterior depression of the 2nd metasomal terga more or less weaker and metasomal terga less shiny. This subspecies is very similar to kamikochiana of Honshu (central and northern), Japan, but can be separable from the latter by the characters given in the key.

According to the collecting data, this subspecies appears in late July, followed by a gradual increase in August. In Hokkaido, this species flies earlier and inhabits higher mountainous regions than Andrena mitakensis does.

Female: Length about or less than $8.0 \mathrm{~mm}$.

Colour: Black; mandibles reddened apically; flagellum brownish beneath ; wings more or less distinctly brownish subhyaline ; veins and stigma yellowish brown; tegulae narrowly brownish subhyaline posteriorly, the rest of it black- 

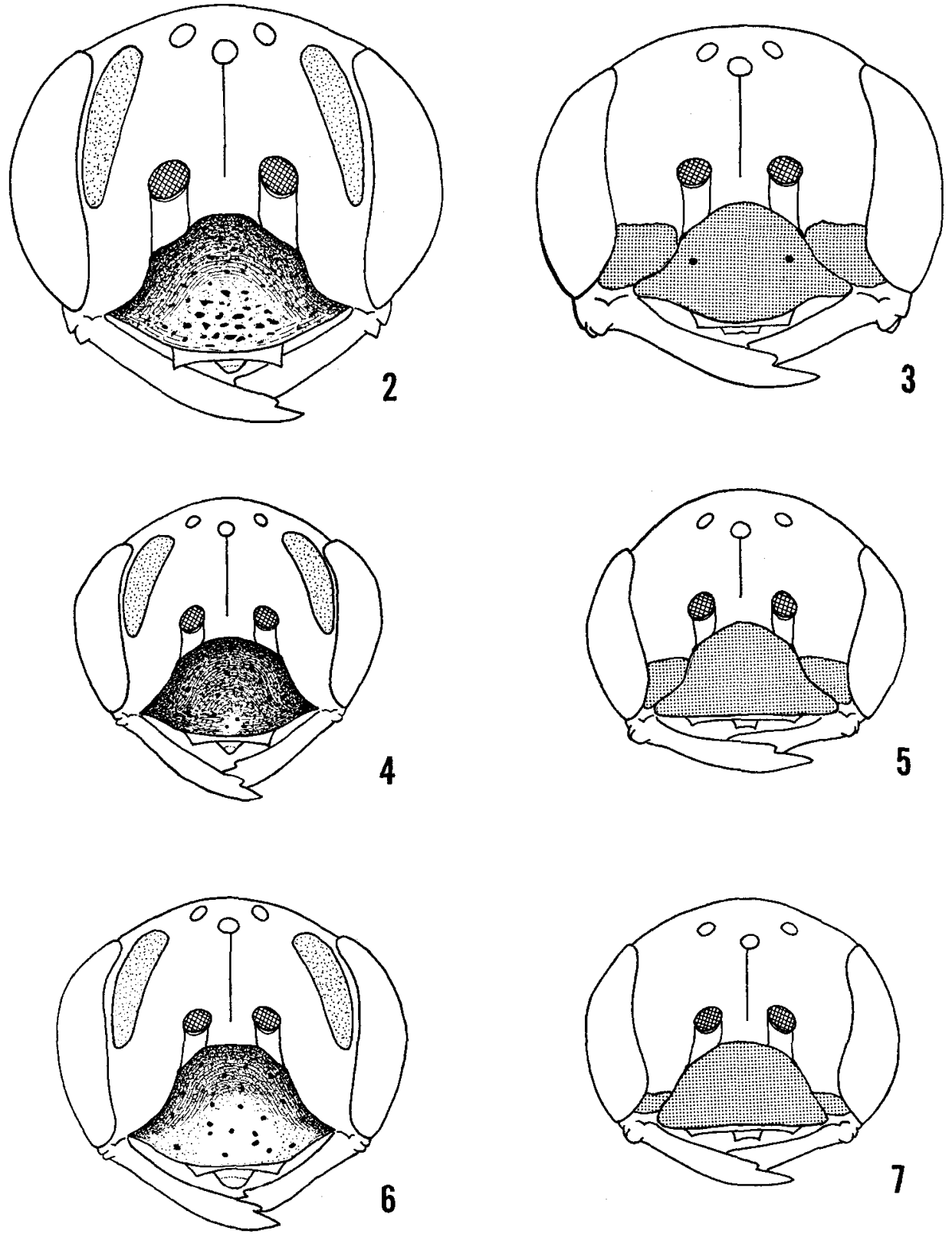

Pips. 2-7. Front views of heads of Andrena (Oreomelissa), females (left) and males (right). 2, 3: mitakensis Hirashima. 4, 5: kamikochiana Hirashima. 6, 7: coitana pilosodorsata Alfken. (Drawn to the same scale).

ened; legs piceous, tarsi brownish; tibia1 spurs yellowish brown ; metasoma piceous basally with posterior margins of terga yellowish brown subhyaline.

Pubescence: Hairs on head and thorax short to more or less long, sparse, 


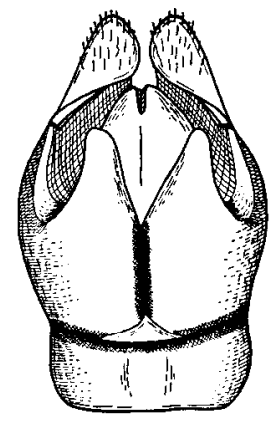

a

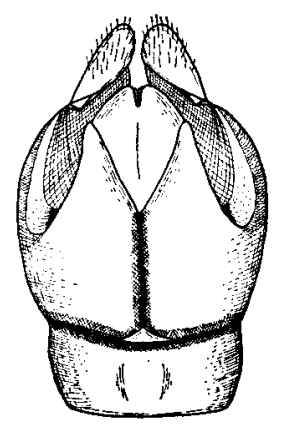

12

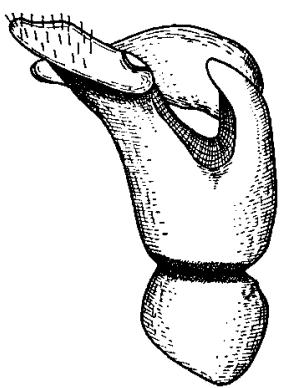

9

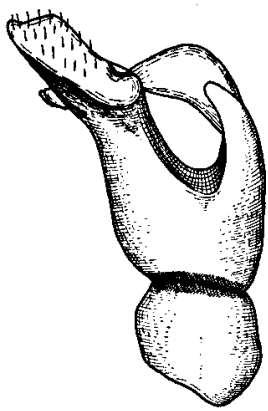

13

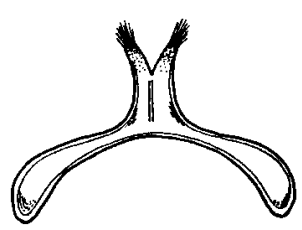

10

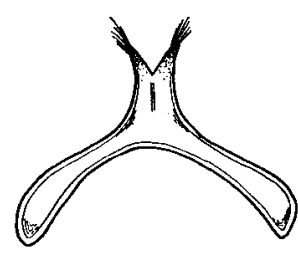

14

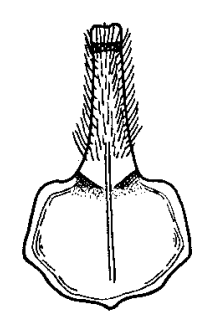

11

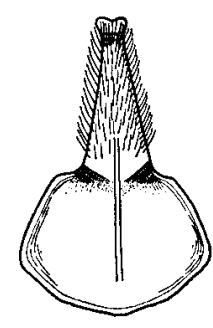

15

Figs. 8-15. Genitalia and associated structures of Andrena (0 reomelissa). 8-11 : kamikochiana Hirashima, 8-9, genitalia, 10, 7th sternum, 11, 8th sternum. 12-15: coitana pilosodorsata Alfken, 12-13, genitalia, 14, 7th sternum, 15, 8th sternum.

those on metasoma short, scanty (shorter and sparser in coitana coitana); hairs on head brownish except for whitish hairs on occiput and cheeks below; facial fovea blackish, bright in some light ; hairs on mesoscutum brown medially, paler or whitish on periphery, not conspicuous ; hairs on scutellum brown anteriorly, long and paler laterally; dorsal fringe of propodeal corbicula scanty, not well arranged ; interior of corbicula with short, fine hairs ; trochanteral floccus nearly perfect, not dense, white ; femoral floccus scanty, silver white ; tibia1 scopa large, composed of long, dense, simple, brown hairs ; cilia on metasomal terga brownish ; caudal fimbria brown; posterior margin of 2 nd tergum with lateral, that of 3 rd with more broad, that of 4th with more broad fringes of short, appressed, white hairs; hairs on metasomal sterna brownish medially, paler or whitish laterally (brownish in kamikochiana).

Structure: Head of moderate size, as broad as thorax seen from above; mandibles moderately long, robust; malar space very narrow anteriorly, widened posteriorly; process of labrum more or less larger than in kamikochiana, triangular, slightly but broadly convex ; clypeus well convex, tessellate basally, nearly smooth and shiny apically, sparsely and irregularly punctate with punctures 
becoming slightly stronger and coarser toward apex of clypeus (densely and strongly punctate in coitana coitana) ; lower paraocular areas weakly tessellate with an indication of weak punctures; facial fovea deep, separated from eye margin by a more or less narrow, punctate, shiny, raised space, with upper end occupying more than one-half of distance between orbit and post ocellus (facial fovea deeper and raised space narrower in kamikochiana) ; antennae with 3rd seg-

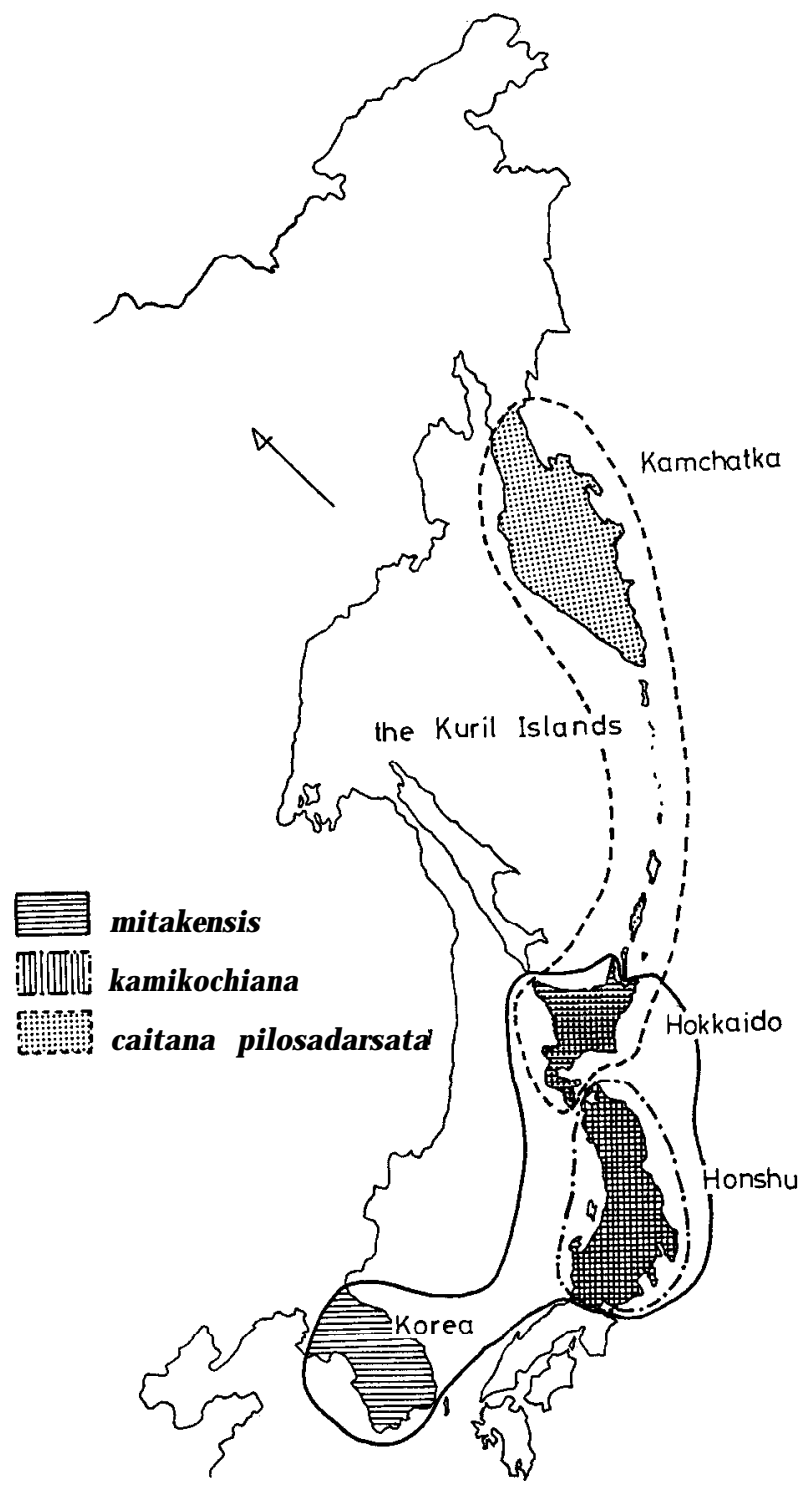

Fig. 16. Map showing the distribution of the three Asian species of Andrena(Oreomelissa). 
ment approximately as long as 4th plus 5th which are broader than long respectively ; frons densely longitudinally striate (coarsely sculptured in kamikochiana) ; vertex well developed, arched in front view, tessellate or nearly shagreened with very weak punctures (more or less densely tessellate in kamikochiana) ; ratio of postocellar width to ocelloccipital distance to postocellar distance to ocellocular distance about 0.5: 1.0: 1.2: 1.9; cheeks about as broad as eyes seen in profile, rather convex, broadly tessellate posterioriy, narrowly smooth and weakly punctate near cyes (more or less densely tessellate in kamikochiana) ; subgenal coronet well developed; maxillary palpi longer than galea by last two palpal segments when both are extended. Pronotum tessellate with weak punctures ; mesoscutum tessellate, more densely so anteriorly, very weakly and sparscly punctate, feebly shiny (more densely tessellate in kamikochiana, more densely and strongly punctate in coitana coitana); scutellum well convex, nearly smooth or weakly tessellate. punctate ; dorsal face of propodcum tessellate and slightly punctatc (densely tessellate and impunctate in kamikochiana) ; enclosure large, nearly triangular, ill defined, weakly wrinkled basally, nearly shagreened apically ; mesopleuron nearly shagreened anteriorly, posterior portion of mesopleuron as well as lateral face of propodeum densely and finely tessellate. Wings with 2nd submarginal cell nearly parallel-sided, receiving 1st reccurent vein beyond middle or near end of cell; 1st intercubital vein close to pterostigma. Legs with mid basitarsi scarcely expanded medially, narrower than hind basitarsi ; hind basitarsi slender. Metasomal terga shiny; 1st to 4th metasomal terga microscopically tessellate with sparse and microscopical fine punctures (densely and more or less strongly punctate in coitana coitana) ; posterior depressions of metasomal terga broad, more or less well indicated (poorly indicated in kamikochiana) ; pygidial plate v-shaped ; metasomal sterna weakly tessellate.

Male: Length about $7.0 \mathrm{~mm}$ or occasionally smaller.

Colour : Black ; clypeus entirely and lower paraocular areas narrowly ivory white (broadly so in kamikochiana) ; clypeus occasionally with a pair of black spots sublaterally ; mandibles reddened apically ; flagellum blackish brown beneath ; wings slightly brownish, distal margins a little more darkened ; veins and stigma brownish ; tegulae shiny brown ; legs piceous with tarsi brown ; metasoma nearly piceous, with posterior margins of terga pale brownish subhyaline.

Pubescence: Hairs on head and thorax short to more or less long, not dense (shorter and sparser in coitana coitana and kamikochiana) ; hairs on clypeus sparse, suberect, white; hairs on the rest of head slightly denser, white or whitish on lower paraocular areas and cheeks below, brownish to brown on face, frons, vertex and cheeks above; hairs on mesoscutum and mesoscutellum more or less long, brownish and whitish on mesoscutum anteriorly and on scutellum posteriorly; hairs on propodeum and mesopleuron white ; 1st tergum hairy only laterally ; cilia on 2nd and following terga brownish ; hairs on 5th and 6th terga brownish ; 2nd and 3rd terga with lateral fringes of somewhat sparse, suberect, white hairs posteriorly; similar and less evident hairs present on posterior margin of 4 th tergum laterally; metasomal sterna with whitish hairs.

Structure: Head more or less large, slightly broader than thorax seen from above ; mandibles moderately long, rather robust, with lower teeth not much ex- 
ceeding upper ones, not specially curved; malar space very narrow anteriorly, widened posteriorly ; process of labrum protuberant ; clypeus slightly convex, nearly semicircular, nearly smooth, shiny, sparsely and weakly punctate (prolonged laterally in kamikochc'ana) ; lower paraocular areas weakly tessellate, rather densely punctate with punctures about as strong as or slightly stronger than those on clypeus (more or less densely tessellate in kamikochiana); frons coarsely sculptured; antennae with 3rd segment about twice as long as broad, more or less shorter than 4th plus 5th; vertex well developed, arched in front view, densely tessellate or nearly shagreened with punctures; ratio of postocellar width to ocelloccipital distance to postocellar distance to ocellocular distance about $0.5: 0.9: 0.9: 1.8$; cheeks broader than eyes seen in profile, well convex above, very slightly receding below, tessellate posteriorly, smooth and weakly punctate near eycs. Mesoscutum tessellate, densely so anteriorly and weakly so or narrowly nearly smooth medially, sparsely and weakly punctate with punctures hardly stronger than those on clypeus (more densely and strongly punctate in coitana coitana) ; scutellum strongly convex, tessellate with weak punctures (nearly smooth and shiny in coitana coitana) ; dorsal face of propodeum densely tessellate or nearly shagreened, dull ; enclosure large, nearly triangular, poorly defined,weakly wrinkled basally, shagreened elsewhere ; mesopleuron densely tessellate or nearly shagreened anteriorly. Wings nearly as in female. Legs slender, as usual. Mctasoma shiny: 1st tergum smooth, scattered with microscopical fine punctures; 2nd and following terga tessellate basally, smooth apically, with punctures; posterior depressions of 4 th terga weakly indicated; 6th sternum reflexed apically; 7th sternum deeply emarginate apically, apical lobes distinctly pointed with more or less long hairs; 8th sternum tapered with abundant hairs ; genital capsule with parapeninl lobes slender: penis valves broadened basally.

Distribution : Japan (Hokkaido), the Kuril Islands (Kunashiri Is., Shikotan Is. and Etorofu Is.) and Kamchatka. This is the first record of this species from Hokkaido and the Kuril Islands.

Flower record : Not available.

Specimens examined: Hokkaido: $3 \precsim \precsim$, Sôunkei Spa, Mt. Daisetsu, 27. vii. 1974

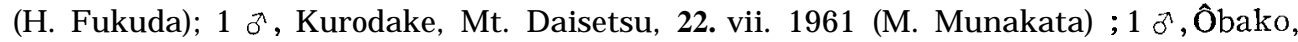
Mt. Daisetsu, 20. vii. 1974 (H. Fukuda) ; $3 \precsim \precsim$, Ryokuunbashi, Mt. Daisetsu, 20. vii. 1974 (H. Fukuda) ;2 え, Nishiashoro, Tokachi, 6. viii. 1953 (Y. Hirashima); 1 ๖, Ikomanbetsu, Mt. Daisetsu, 23-25. vii. 1955 (Y. Hirashima) ; 7 우우, Kitamoshiri, Hokkaido Uryû Exp. Forests, 9-14. ix. 1969 (S. F. Sakagami and

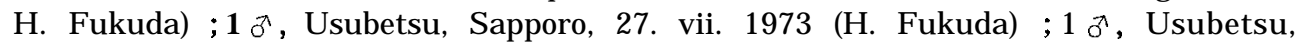
Sapporo, 23. viii. 1973 (H. Fukuda) ; $2 \precsim ð$, Otarunai near Jôzankei, Sapporo, 25. vii. 1973 (H. Fukuda) ; 1 우, Otarunai near Jôzankci, Sapporo, 24. viii. 1973 (H. Fukuda). The Kuril Islands: 5 우우 $9 \widehat{\diamond} \widehat{\jmath}$, Kunashiri Is. (S. Kuwayama and Y. Sugihara) ; 1 , Shikotan Is. (S. Kuwayama and Y. Sugihara); 1 ㅇ, Etorofu Is. (S. Kuwayama and Y. Sugihara). 


\section{ACKNOWLEDGEMENTS}

We are grateful to the following entomologists for loan or gift of specimens which were useful for the present study: Dr. S. F. Sakagami and Mr. H. Fukuda of Hokkaido Univ., Dr. S. Kuwayama of Sapporo (through Mr. H. Hasegawa of Hokkaido Nat. Agr. Exp. Stat.), Mr. Y. Maeta of Tohoku Nat. Agr. Exp. Stat., Dr. I. Togashi of Ishikawa Agr. College, Miss M. Honda of Ryukyu Univ. and Mr. Y. Haneda of Ono City, Fukui Pref.

\section{REFERENCES}

Alfken, J. D. 1929 Entomologische Ergebnisse der schwedischen Kamtschatka-Expedition 1920-1922. 21. Apidae, excl. genus Bombus. Ark. Z ool., 20A, 16: l-8

Hedicke, H. 1933 Beiträge zur Systematik der Gattung Andrena F. (Hym. Apoid.). Mitt. Zool. Mus., Berlin, 19: 199-220

Hirashima, Y. 1963 Systematic and biological studies of the family Andrenidae of Japan (Hymenoptera, Apoidea). Part 2. Systematics, 2. J.Fac. Agr., Kyushu Univ., 12: 241263

Hirashima, Y. 1966 Systematic and biological studies of the family Andrenidae of Japan (Hymenoptera, Apoidea). Part 2. Systematics, 7. J. Fac. Agr., Kyushu Univ., 14: 89-131

LecLercq, J. (édité) 1972 Atlas provisoiredes insectes de Belgique, Carte 607. Fac. Sci. Agronom. Etat. Zool. Gener. Faunist., Gembloux

Matsumura, T. and M. Munakata 1969 Relative abundance, phenology and flower preference of andrenid bees at Hakodateyama, Northern Japan (Hymenoptera, Apoidea). J. Fac. Sci. Hokkaido Univ., Ser. 6, Zool., 17: 106-126

Munakata, M. 1971 Relative abundance, phenology and flower preference of andrenid bees at Akagawa near Hakodate, Northern Japan, Hymenoptera, Apoidea. J. Hokkaido Univ. Educ. (Sect. II B), 22: 26-39

Sakagami, S. F. and H. Fukuda 1972 Autumn bee fauna in Hokkaido University Uryû and Nakagawa Experiment Forests. Res. Bull. Coll. Exp. For., Coll. Agr., Hokkaido Univ., 29: $1-24$ (in Japanese)

Tadauchi, 0. Numerical phenetic relationships of the genus Andrena (Hymenoptera, Andrenidae) of Japan, with a new introduction of component pattern diagrams. (in press)

Warncke, K. 1968 Die Untergattungen der westpallarktischen Bienengattung Andrena F. Mem. Est. Mus. Zool. Univ. de Coimbra, (307) : 1-110

Yasumatsu, K. 1941 A list of the Far Eastern species of the genus Andrena (Hym., Apoidea). Peking nat. Hist. Bull., $15: 273-284$ 